traditional sources - pituitary glands taken from cadavers. After the upheavals in this business brought about by the introduction of payments to mortuary attendants for extracting pituitaries, the Department of Health seems happy with the way things are going. Whether Porton will become a manufacturer of cloned growth hormone, perhaps under licence, remains to be seen. Certainly the laboratory plans to sell its services in helping commercial biotechnology companies scale up procedures.

The staff at Porton seems to have survived the upheavals of the past five years in reasonably good shape. Departures and new arrivals have been reduced to trickles. The scientific staff of 70 is an unusually small proportion of the total of 400 (including janitors), reflecting for example the large numbers of technicians operating semi-production equipment.

\section{Environmental legislation} \section{Problems persist}

\section{Washington}

As Congress returns this week from its Independence Day recess, it will continue its long drawn out effort to dispose of two controversial scientific issues, the Clean Water Act and the Clean Air Act.

Last month, the Administration introduced its long-awaited proposals for amending the Clean Water Act. Although both industry and environmentalist groups find fault with points in the Administration package (filed as S 2652), the disagreements seem minor. Environmentalist groups object to a proposed relaxation in the current mandatory requirements that industries pretreat any wastes discharged into municipal sewage systems; industry seems more upset by the omissions of the proposed amendments - specifically, that no waivers would be granted to the act's requirements on wetlands protection or on the installation of "best available technology" for the control of hazardous substances in waste streams.

But despite the relative measure of agreement, it has become increasingly clear that Congress will choose to get involved in modifying the act this year. The Senate's environmental pollution subcommittee of the Committee on Environment and Public Works has scheduled hearings for the last two weeks of July. But Congress's heavy schedule of unfinished business, and the reluctance to deal with even mild controversy in an election year may be formidable obstacles to any further steps. An easy way out is available through another bill (S 2590) which would merely authorize continued funding for the act (due to run out on 30 September) while making no changes at all in its substance.

It is even less likely that action will be taken on the rewriting of the Clean Air Act, which has already been bogged down for over a year. Representative John Dingell
(Democrat, Michigan), chairman of the House Energy and Commerce Committee, had earlier this year put together a coalition - with Administration backing - behind a bill (HR 5252) that would significantly ease the air pollution limits imposed on new automobiles. Specifically, it would double carbon monoxide and nitrogen oxide emission limits and make it harder for the Environmental Protection Agency (EPA) to order recalls on new cars not meeting the standards. The bill would also weaken the complex "prevention of significant deterioration" provisions of the act, which are designed to limit pollution increases in already clean regions. The Dingell bill would eliminate these provisions for all areas except National Parks, and would, according to EPA estimates, roughly double the allowable emissions even in these remaining areas.

When the bill reached the full committee, after clearing the health and environment subcommittee, the coalition started getting shaky. In April, Dingell suspended work on the bill.

Meanwhile in the Senate, prospects that a bill will be passed are becoming very dim. Many people, however, consider that may be the best result. Although the "authorization for appropriation' ran out for the act last September, it remains in force, and Congress last year had no trouble appropriating operating funds for EPA that enabled it to continue to enforce the act. And as one committee staff member puts it, everybody gets something from the continued stalemate. Environmentalists get the continued force of the tough old law, undiluted by concessions to industry, while industry - particularly the utility industry - is spared the burden of regulations aimed at curbing acid rain, which is something the Senate committee wants added to the act. There may be growing sentiment for a bill that would do little more than extend the deadlines that the present act sets for states to meet air quality goals.

\section{Stephen Budiansky}

\section{Polish martial law \\ Hope deferred}

Martial law in Poland has fulfilled its purpose, police chief General Jozef Bejm observed on Warsaw television last weekend. This has raised hopes that the anniversary of the foundation of the Polish People's Republic on 22 July could see further relaxations of the regulations, and possibly the conversion of the present "state of war" into a civilian state of emergency. Some commentators have suggested that this could lead to at least a partial lifting of US sanctions against the Soviet bloc. Recent events, however, suggest that in Polish academic life any lightening of the restrictions would be little more than cosmetic.

During the past few weeks, in spite of the release of a number of detainees, there have been disturbing unofficial reports of new internments. Participants at the recent European Physical Society meeting, for example, heard of the internment in May of a young researcher, Miroslaw Hamera, from the Physics Institute of the Polish Academy of Sciences in Wroclaw, apparently in connection with the demonstrations over the May Day weekend.

Such internments without formal charge are not generally reported in Poland. When formal charges are preferred, however, the publicity is considerable, as in the case of Dr Ryszard Herczynski who last month received a two-year prison sentence for attempting to send to the West materials containing allegedly false information on the current situation and urging Polish scholars to resist martial law.

One of the documents mentioned in the Herczynski case is a "code of conduct" for academics during martial law. The text of this has not reached the West, but appears to urge non-cooperation with the authorities. Meanwhile, a debate has blown up between the new government daily Rzeczpospolita and the once-liberal weekly Polityka on the growing trend in intellectual life towards "internal emigration" - defined as retreat into purely academic interests.

Apparently prompted by a meeting towards the end of June between General Jaruzelski and Professor Aleksander Gieysztor, chairman of the Polish Academy of Sciences, the academy's Consultative Committee for Social and Scientific Initiatives announced its intention of becoming a platform for discussion between scientists and the authorities. The committee has called on all members and employees of the academy to cooperate with the committee regardless of their past or present affiliations. So far, the response has not been enthusiastic, and last week General Mieczyslaw Moczar, head of the government's Supreme Auditing Chamber, complained to the Sejm (Parliament) about the "meagre" role being played by Polish science in modernizing the economy.

Similarly there has been a hiatus in the political "verification" of university personnel, which should have been completed by the end of the academic year. Verification procedures have, however, been blocked in universities with resistance ranging from the "mislaying" of the necessary forms to written protests from departmental councils to the Ministry of Science, Higher Education and Technology. Four University of Warsaw department heads categorically refused to "verify" their subordinates.

The timing is important. If the procedures had been completed by the end of term, unverified academics could have been sacked during the vacation without their students' knowledge - and before the entry into force on 1 September of the new Higher Education Act, which assures university autonomy.

Vera Rich 